\section{Facilitation of performance in pigeons by low-intensity electric shocks*}

\author{
T. M. BLOOMFIELD
}

York University, Downsview, Ont., Canada

Random shocks of short duration in one of two stimuli were found to facilitate pigeons' pecking when shock intensities were low, while at higher shock levels the usual suppressive effects were found. Most other investigators may have failed to find similar effects through the use of higher intensities and longer durations or from use of a fixed-length signal terminating in shock. The result suggests that mild brief shock can increase rewarded activity.

One important issue in learning theory is the role of general states of activation or arousal. Hull (1943) supposed that a drive state, induced by deprivation, had general excitatory effects on behavior. Later this view was considerably qualified (Hull, 1952), but similar questions arose with the growth of theories of incentive motivation. In his frustration theory, Amsel (1958) assumed that the frustrating consequences of the absence of an expected reward were generally arousing as well as aversive and associated with characteristic stimuli. In partial reinforcement situations, the faster running often found (e.g., Wagner, 1961) has been interpreted as supporting the view that frustration increases arousal. However, partial reinforcement situations can be interpreted in a number of ways, and a simpler test of the "general arousal" hypothesis can be made with electric shock. Can the delivery of free shocks facilitate performance?

\section{METHOD}

Three pigeons were trained at $80 \%$ free-feeding body weight to peck a response key illuminated by either red or green light. Reinforcement occurred unpredictably, but on the average $1 / \mathrm{min}$ (VI 1). The red and green stimuli alternated, each present for $1 \mathrm{~min}$ at a time (mult VI 1 VI 1 ). Twenty days of training were given on that schedule, by which time response rates had stabilized. The pretraining period provided a measure of the ratio of response rates on each color. In subsequent training, sessions of shock-free periods were interpolated regularly. Shock was delivered through implanted electrodes (Azrin, 1959) and at random intervals in one color only. Two rates of shock delivery were used, with averages of one or five shocks per minute. The resistance of

* This work was carried out while the author held a U.K. Science Research Council Fellowship at the University of Sussex. Writing the manuscript was supported by Grant No. APA370 from the National Research Council of Canada. suppression, greater than 1 , facilitation.
Table 1

Experimental Procedure

\begin{tabular}{|c|c|c|c|}
\hline $\begin{array}{c}\text { Shock } \\
\text { Intensity } \\
\text { (Volts) }\end{array}$ & $\begin{array}{c}\text { Shocks } \\
\text { Per } \\
\text { Minute }\end{array}$ & $\begin{array}{c}\text { Shock } \\
\text { Stimulus }\end{array}$ & Sessions \\
\hline 0 & 0 & - & 20 \\
\hline 5 & 1 & Red & 6 \\
\hline 5 & 5 & Red & 6 \\
\hline 0 & 0 & - & 6 \\
\hline 10 & 1 & Green & 6 \\
\hline 10 & 5 & Green & 6 \\
\hline 0 & 0 & 一 & 10 \\
\hline 15 & 1 & Red & 6 \\
\hline 15 & 5 & Red & 6 \\
\hline 0 & 0 & - & 10 \\
\hline 20 & 1 & Green & 6 \\
\hline 20 & 5 & Green & 6 \\
\hline 0 & 0 & - & 10 \\
\hline 20 & $\mathbf{5}$ & Red & 6 \\
\hline 20 & 1 & Red & 6 \\
\hline 0 & 0 & - & 10 \\
\hline 15 & 5 & Green & 6 \\
\hline 15 & 1 & Green & 6 \\
\hline 0 & 0 & - & 10 \\
\hline 10 & 5 & Red & 6 \\
\hline 10 & 1 & Red & 6 \\
\hline 0 & 0 & - & 10 \\
\hline 5 & 5 & Green & 6 \\
\hline 5 & 1 & Green & 6 \\
\hline 0 & 0 & - & 10 \\
\hline
\end{tabular}

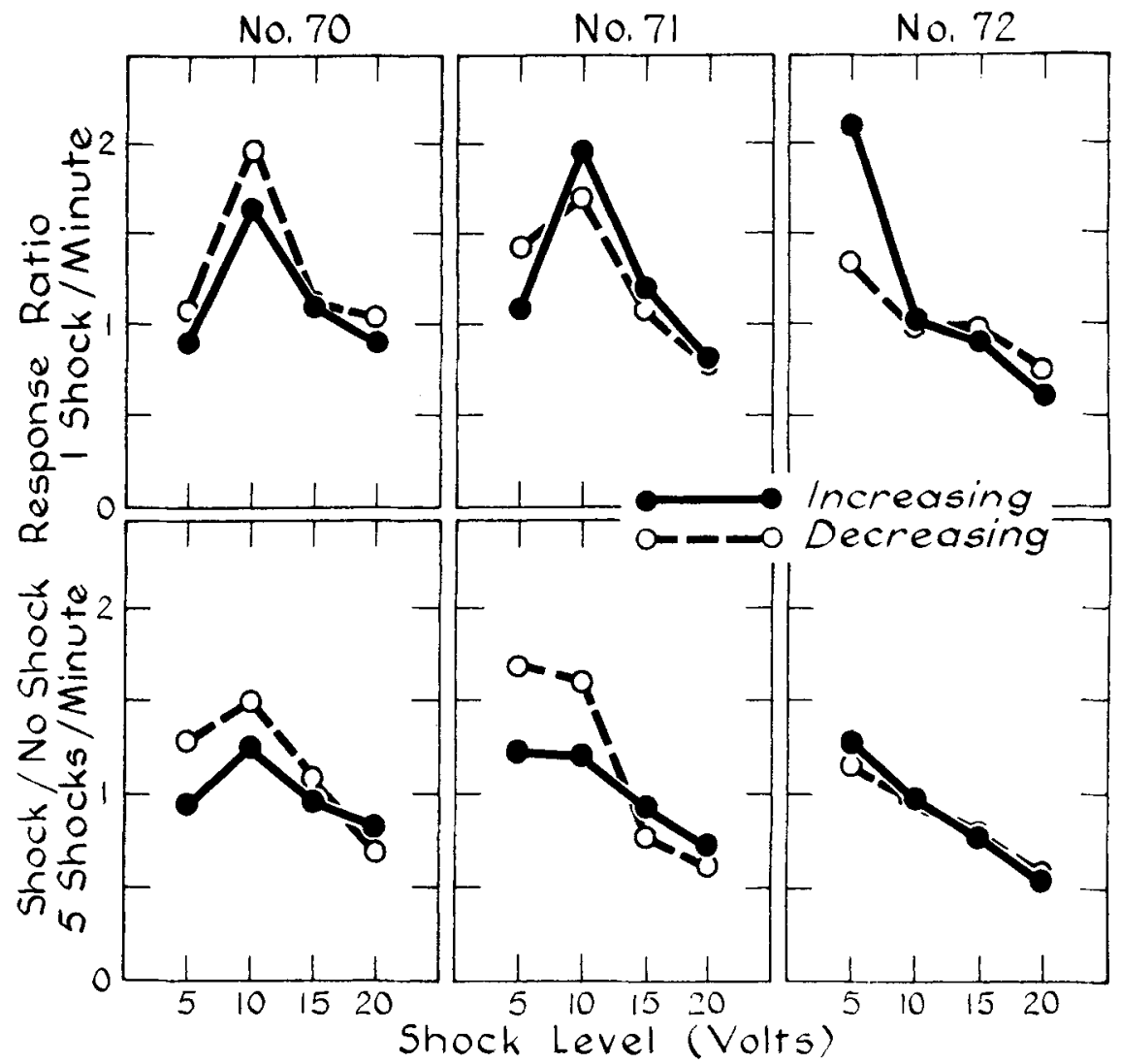

Fig. 1. Ratio of responding in shock periods to responding in no-shock periods as a function of shock intensity. Upper panels show results for a frequency of 1 shock/min and lower panels, 5 shocks/min. A ratio of less than 1 shows 
no-shock responding at increasing levels of shock intensity. The three birds show similar main effects at the two shock rates used. At $5-10 \mathrm{~V}$ (approximately 0.25-0.5 mA) shock increased the rate of responding; at 15-20 V (approximately 0.75-1.0 mA) the usual suppressive effects appeared. DISCUSSION

The results suggest that brief shock of low intensity can facilitate responding on a VI schedule of food reinforcement. Fowler (1963) demonstrated that mild shock given to rats at the end of a straight runway would have that effect, but only if shock was received on the hindpaws. As Logan \& Wagner (1965) argue, Fowler's result may be interpreted in terms of anticipatory responses to shock in the runway and thus is not good evidence for direct facilitatory effects of shock.

The author has found no reports of a facilitatory effect of shock in the literature on conditioned suppression or the conditioned emotional response, except a study by Rachlin \& Herrnstein (1969, p. 92). The authors examined the effects of noncontingent shock on choice and reported increases in the rate of responding in two out of four birds. In general, conditioned suppression studies use a long shock duration of the order of 5-10 sec (e.g., Hoffman, 1965) or at least a duration of approximately $0.5 \mathrm{sec}$ (e.g., Stein et al, 1958; Hearst, 1965). The duration of shock in the present experiment $(30.40 \mathrm{msec})$ is considerably less than in other studies. A further factor that may have helped produce the facilitatory effect found here is the unpredictable presentation of shock. In the studies cited, shock presentation terminated a fixed warning signal. In the present experiment, the "warning signal" was either red or green and shock was delivered at random during the 1-min stimulus period.

Although the result is not evidence for an antedating goal-response approach to motivation, it does support the more general argument that some events can have arousing effects that are not tied to approach or avoidance. Whether a general distinction can be made between intensity and direction of behavior (Duffy, 1963) remains another question.

\section{REFERENCES}

AMSEL, A. The role of frustrative nonreward in noncontinuous reward situations. Psychological Bulletin, 1958,
$55,102-119$.

AZRIN, N. H. A technique for delivering shock to pigeons. Journal of the Experimental Analysis of Behavior, 1959 2, 161-162.

DUFFY, E, Activation and behavior. New York: Wiley, 1963.

FOWLER, H. Facilitation and inhibition of performance by punishment: Effects of shock intensity and distribution of trials. Journal of Comparative \& Physiological Psychology, 1963, 56, 531-538.

HEARST, E. Stress-induced breakdown in an appetitive discrimination. Journal of the Experimental Analysis of Behavior, $1965,8,135-146$.

HOFFMAN, H. S. The stimulus generalization of conditioned suppression. In D. I. Mostofsky (Ed.), Stimulus generalization. Stanford: Stanford University Press, 1965.

HULL, C. L. Principles of behavior. New York: Appleton-Century-Crofts, 1943.

HULL, C. L, A behavior system. New Haven: Yale University Press, 1952.

LOGAN, F. A., \& WAGNER, A. R. Reward and punishment. Boston: Allyn \& Bacon, 1965.

RACHLIN, H. \& HERRNSTEIN, R. J Hedonism revisited: On the negative law of effect. In B. A. Campbell and R. M. Church (Eds.), Punishment and aversive $b$ e $h a v i o r$. $\mathrm{N}$ e $\mathrm{w} \quad \mathrm{Y}$ ○ $\mathrm{r}$ : Appleton-Century-Crofts, 1969.

STEIN, L., SIDMAN, M., \& BRADY, J. V. Some effects of two temporal variables on conditioned suppression. Journal of the Experimental Analysis of Behavior, $1958,1,154-162$.

WAGNER, A. R. Effects of amount and percentage of reinforcement and number of acquisition trials on conditioning and extinction. Journal of Experimental Psy chology, 1961, 62, 234-242.

\section{CURRENT LITERATURE ON AVOIDANCE \& PUNISHMENT IN ANIMALS}

COHEN, D. H. (Department of Physiology, University of Virginia School of Medicine, Charlottesville, Va. 22901), \& MACDONALD, R. L. Some variables affecting orienting and conditioned heart-rate responses in the pigeon. Journal of Comparative and Physiological Psychology, 1971, 74, 123-133.

JAMES, J. P. (Fort Hays Kansas State College, Hays, Kans. 67601). Acquisition, extinction, and spontaneous recovery of conditioned suppression of licking. Psychonomic Science, 1971, 22, 156-158.

KATZEV, R. D. (Reed College, Portland, Oreg. 97202), \& HENDERSEN, $R$. W. Effects of exteroceptive feedback stimuli on extinguishing avoidance responses in Fischer 3 rats. Journal of Comparative and Physiological Psychology, 1971, 74, 66-74.

LACEY, D. J. (Department of Anatomy-Physiology, Indiana University, Bloomington, Ind. 47401). Temporal effects of RNase and DNase in disrupting acquired escape behavior in regenerated planaria. Psychonomic Science, $1971,22,139-140$.

MIKHAIL, A. A. (University of
Manitoba, Winnipeg 19, Manitoba, Canada). Effects of acute and chronic stress situations on stomach acidity in rats. Journal of Comparative and Physiological Psychology, 1971, 74, 23-27.

OLSON, G. H. (University of New Hampshire, Durham, N.H. 08324), \& HAGSTROM, E. Recovery experiences and the source of aversive effects of electroconvulsive shock. Psychonomic Science, 1971, 22, 161-162.

POWELL, B. J. (Malcolm Bliss Mental Health Center and Washington University, St. Louis, Mo. 63104), \& HOPPER, D. J. Effects of strain differences and D-amphetamine sulfate on avoidance performance. Psychonomic Science, 1971, 22, 167.168.

SCHULENBURG, C. J., RICCIO, D. C., \& STIKES, E. R. Acquisition and retention of a passive-avoidance response as a tunction of age in rats. Journal of Comparative and Physiological Psychology, 1971, 74, 75-83.

SCLAFANI, A., \& GROSSMAN, S. P. (University of Chicago, Chicago, Ill. 60637). Reactivity of hyperphagic and normal rats to quinine and electric shock. Journal of
Comparative and Physiological Psychology, 1971, 74, 157-166.

SQUIRE, L. R. (Department of Psychiatry, University of California, La Jolla, Calif. 92037), GLICK, S. D., \& GOLDFARB, J. Relearning at different times after training as affected by centrally and peripherally acting cholinergic drugs in the mouse. Journal of Comparative and Physiological Psychology, 1971, 74, 41-45.

STEINER, G. (RPH-1, Massachusetts General Hospital, Boston, Mass. 02114). Stimulus control of avoidance learning in fish. Journal of Comparative and Physiological Psychology, 1971, 74, 52-58.

UHL, C. N. (University of Utah, Salt Lake City, Utah 84112), \& SHERMAN, W. O. Comparison of combinations of omission, punishment, and extinction methods in response elimination in rats. Journal of Comparative and Physiological Psychology, 1971, 74, 59-65.

YOUNG, A. G. (Louisiana State University, Baton Rouge, La. 70803), \& GALLUSCIO, E. H. Recovery from ECS-produced amnesia. Psychonomic Science, $1971,22,149-151$. 